\title{
Sugar Import and Phytopathogenicity of Spiroplasma citri: Glucose and Fructose Play Distinct Roles
}

\author{
Aurélie André,, ${ }^{1}$ Mickaël Maucourt, ${ }^{2}$ Annick Moing, ${ }^{2}$ Dominique Rolin, ${ }^{2}$ and Joël Renaudin ${ }^{1}$ \\ ${ }^{1}$ UMR 1090 Génomique Développement et Pouvoir Pathogène, INRA, Université de Bordeaux 2, Centre INRA de Bordeaux, \\ 71 avenue Edouard Bourlaux, B.P. 81, 33883 Villenave d'Ornon Cedex, France; ${ }^{2}$ UMR 619 Physiologie et Biotechnologie \\ Végétales, INRA, Université de Bordeaux 1 et Université de Bordeaux 2, Centre INRA de Bordeaux, 71 avenue Edouard \\ Bourlaux, B.P. 81, 33883 Villenave d'Ornon Cedex, France
}

Submitted 3 June 2004. Accepted 30 August 2004.

\begin{abstract}
We have shown previously that the glucose PTS (phosphotransferase system) permease enzyme II of Spiroplasma citri is split into two distinct polypeptides, which are encoded by two separate genes, $c r r$ and $p t s G$. A $S$. citri mutant was obtained by disruption of $p t s G$ through homologous recombination and was proved unable to import glucose. The ptsG mutant (GII3-glc1) was transmitted to periwinkle (Catharanthus roseus) plants through injection to the leafhopper vector. In contrast to the previously characterized fructose operon mutant GMT 553, which was found virtually nonpathogenic, the pts $G$ mutant GII3-glc1 induced severe symptoms similar to those induced by the wild-type strain GII-3. These results, indicating that fructose and glucose utilization were not equally involved in pathogenicity, were consistent with biochemical data showing that, in the presence of both sugars, $S$. citri used fructose preferentially. Proton nuclear magnetic resonance analyses of carbohydrates in plant extracts revealed the accumulation of soluble sugars, particularly glucose, in plants infected by $S$. citri GII-3 or GII3-glc1 but not in those infected by GMT 553. From these data, a hypothetical model was proposed to establish the relationship between fructose utilization by the spiroplasmas present in the phloem sieve tubes and glucose accumulation in the leaves of $S$. citri infected plants.
\end{abstract}

Additional keywords: carbohydrate metabolism, plant pathogenic mollicute, ${ }^{1} \mathrm{H}-\mathrm{NMR}$.

Spiroplasma citri is a plant pathogenic bacterium belonging to the class Mollicutes, a group of wall-less microorganisms phylogenetically related to low $\mathrm{G}+\mathrm{C}$, gram-positive bacteria (Weisburg et al. 1989). Plant pathogenic mollicutes have been associated with several hundred diseases affecting economically important crops, such as ornamentals, vegetables, fruit trees, and grapevine (Lee et al. 2000; McCoy et al. 1989; Seemüller et al. 1998, 2002). However, the mechanisms by which plant mollicutes induce diseases are still to be deciphered. In host plants, bacteria are restricted to the phloem sieve tubes and are transmitted between plants by phloem sapfeeding leafhoppers or psyllids in a persistent manner. Plant mollicutes range within two taxonomically distinct groups, Candidatus Phytoplasma spp. and Spiroplasma spp. Phyto-

Corresponding author: J. Renaudin; Telephone: (33) 5.57.12.23.61; Fax: (33) 5.57.12.23.69; E-mail: renaudin@bordeaux.inra.fr plasmas have not been cultured in vitro. In contrast, spiroplasmas, in particular S. citri, have been cultured since 1970 (Saglio et al. 1971). S. citri is the causal agent of citrus stubborn and horseradish brittle root diseases (Fletcher 1983; Saglio et al. 1973). It infects many other plants, including the herbaceous plant Catharanthus roseus (periwinkle), in which it induces stunting, leaf yellows, and wilting. $S$. citri is currently the most studied plant mollicute, and many features have been elucidated (Bové 1997; Bové et al. 1989). More recently, the development of adequate genetic tools and methods such as plasmid vectors (Lartigue et al. 2002; Renaudin et al. 1995; Ye et al. 1994), transposon mutagenesis (Foissac et al. 1997a), and specific gene targeting (Duret et al. 1999; Gaurivaud et al. 2000c), together with the experimental transmission of S. citri to periwinkle plants by its leafhopper vector Circulifer haematoceps (Foissac et al. 1996) has opened the way to genetic studies. The availability of spiroplasma mutants led to identification of genes involved in motility, insect transmission, and pathogenicity (Boutareaud et al. 2004; Bové et al. 2003; Duret et al. 1999, 2003; Foissac et al. 1997b; Gaurivaud et al. 2000a; Jacob et al. 1997; Renaudin 2002). Phytoplasmas also multiply in periwinkle plants, in which they induce disorders such as leaf yellows, proliferations, flower malformations, and stunting, similar to those observed in their original hosts. Therefore, $S$. citri represents a model organism to investigate how plant pathogenic mollicutes cause diseases in plants. Over the years, several mechanisms have been suggested to explain phytopathogenicity of $S$. citri. Toxin and lactic acid production have been suggested as possible factors (Daniels 1979, 1983). It was also shown that $S$. citri infection caused a shortage of auxins, and it was proposed that utilization of sterols could result in a deficit in growth regulators (Chang 1998). However the breakthrough came from genetic studies showing that $S$. citri mutants unable to import fructose produced very mild symptoms (Foissac et al. 1997b; Gaurivaud et al. 2000a). In the socalled "nonpathogenic" mutants, the defective import system was proved to be the permease of the phosphoenolpyruvate/fructose phosphotransferase system (fructose PTS), indicating that PTS is the major import system of carbohydrates in S. citri. In addition, functional complementation of the mutants with wild-type genes revealed a perfect correlation between the ability of the spiroplasmas to import fructose and their ability to induce severe symptoms in the plant (Gaurivaud et al. 2000a and b). From these studies, it was hypothesized that fructose utilization by the wild-type spiroplasmas deprives the companion cells of the fructose they need to load sucrose into 
the sieve tubes, leading to impaired partitioning of carbohydrates in the plant, with ensuing symptoms such as leaf yellows and stunting (Bové et al. 2003; Gaurivaud et al. 2000a). In many plants, sucrose represents the major carbohydrate in the phloem sieve tubes, whereas the concentrations of glucose and fructose are very low (Chino et al. 1991; Ziegler 1975). In vitro, S. citri uses fructose and glucose but not sucrose (Chang et al. 1994). Therefore, fructose and glucose, which diffuse from the companion cells into the sieve tube elements, are believed to play the same nutritional role. To further study the role of sugar metabolism in the pathogenicity of $S$. citri, we envisioned the construction of glucose-minus mutants through inactivation of the glucose PTS permease. In previous studies, we have shown that the glucose permease enzyme II of $S$. citri is split into two distinct polypeptides, IIA ${ }^{\mathrm{Glc}}$ and IICB ${ }^{\mathrm{Glc}}$, encoded by the two separated genes $\mathrm{crr}$ and $p t s G$, respectively (André et al. 2003). In the present work, a S. citri mutant unable to import glucose was obtained through inactivation of $p t s G$ by homologous recombination and was characterized. Unexpectedly, this mutant proved to be highly pathogenic, as it induced severe symptoms in the host plant. Proton nuclear magnetic resonance $\left({ }^{1} \mathrm{H}-\mathrm{NMR}\right)$ analyses of carbohydrates revealed an accumulation of carbohydrates in the leaves of plants infected by the $p t s G$-disrupted mutant or the wild-type strain but not in those of plants infected by the fructose mutant GMT 553 , indicating that fructose and glucose play distinct roles.

\section{RESULTS}

\section{Isolation of a pts $G$-disrupted $S$. citri mutant.}

To achieve inactivation of $p t s G$, a strategy based on a single crossover recombination was used. The disruption vector pAA4 was constructed by inserting a 1.4-kbp internal fragment of $p t s G$ into the replicative oriC plasmid $\mathrm{pC} 1$ and was introduced into $S$. citri by electroporation. We have previously shown that, in $S$. citri, the use of replicative plasmid vectors enhances the probability for recombination (Duret et al. 1999; Lartigue et al. 2002). Transformation of $S$. citri GII-3 with pAA4 yielded tetracycline-resistant colonies at a frequency of $2 \times 10^{-5}$ transformants per CFU. A total of 20 spiroplasmal transformants were grown in $\mathrm{SP} 4{ }^{\mathrm{Fru}}$ medium containing tetracycline, and individual clones were subcultured for 15 successive passages, to select clones in which plasmid recombination had occurred at $p t s G$. During passaging of the spiroplasmal transformants, stability of the plasmid was assessed by Southern blot hybridiza- tion of genomic DNA at passages P5, P10, and P15. At P5 and P10, all 20 transformants tested were shown to contain pAA4 as a free, extrachromosomal DNA, as revealed by the detection of a 5.2-kbp HindIII fragment hybridizing with the $p t s G$ probe in addition to the 2.9-kbp fragment corresponding to the wildtype gene (Fig. 1A). In contrast, after 15 passages, hybridization pattern of transformant 8 revealed an additional HindIII fragment of $3 \mathrm{kbp}$, suggesting that plasmid integration might have occurred in some cells (Fig. 1B, lane 2). However, in spite of further passaging, selection of the recombinant did not occur spontaneously. The 2.9-kbp chromosomal fragment was still detected, indicating that spiroplasma cells still carried the wild-type ptsG. In an attempt to isolate the spiroplasma cells in which recombination might have occurred, a culture of clone 8 was grown for five additional passages in the absence of selection pressure to favor plasmid loss and then was plated in the presence of $5 \mu \mathrm{g}$ of tetracycline per ml. Under these conditions, only spiroplasma cells in which the plasmid has integrated into the chromosome should have retained the ability to grow in the presence of tetracycline. Indeed, Southern blot
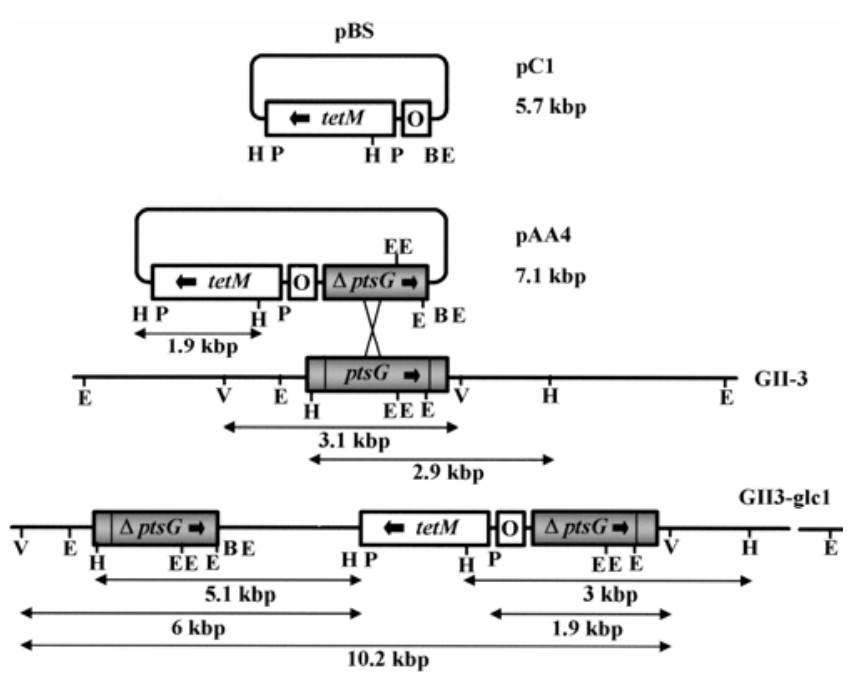

Fig. 2. Partial restriction maps of plasmids $\mathrm{pC} 1$ and $\mathrm{pAA} 4$, and schematic representation of pAA4 integration by recombination at ptsG. $\mathrm{O}=$ Spiroplasma citri oriC, tet $M=$ tet $M$ gene of $T n 916, \Delta p t s G=$ truncated $p t s G . \mathrm{B}$ $=$ Bam $\mathrm{HI}, \mathrm{E}=$ EcoRI, $\mathrm{V}=E c o \mathrm{RV}, \mathrm{H}=$ HindIII, and $\mathrm{P}=$ PstI. Arrowheads indicate direction of transcription.
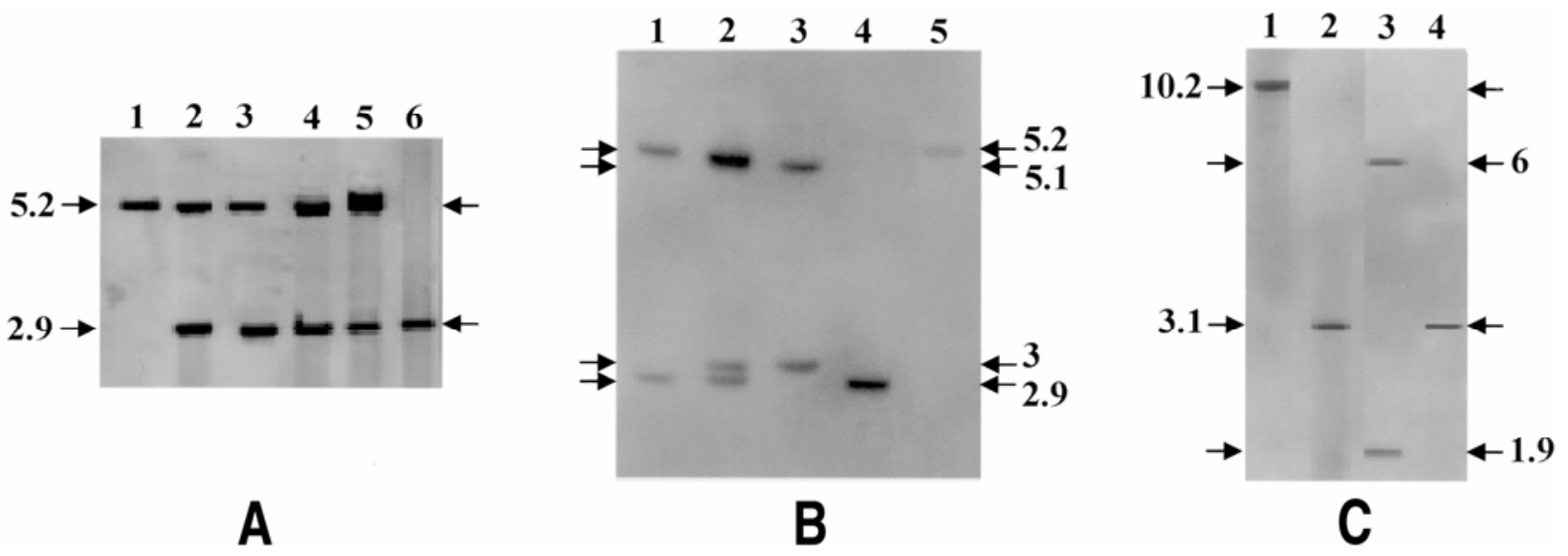

Fig. 1. Southern blot hybridization between restricted DNA of Spiroplasma citri transformants and the ptsG probe. A, Purified pAA4 (lane 1), DNA extracted from various transformants at passage P10 (lanes 2 to 5), and DNA from S. citri GII-3 (lane 6) were restricted by HindIII. B, HindIII-restricted DNA from transformant 8 at P10 (lane 1), P15 (lane 2), and after further selection of the recombinant cells (lane 3), S. citri GII-3 (lane 4), and pAA4 (lane 5). C, DNA from the ptsG-disrupted mutant GII3-glc1 (lanes 1 and 3) and S. citri GII-3 (lanes 2 and 4) were restricted by EcoRV (lanes 1 and 2) or EcoRV plus PstI (lanes 3and 4). Sizes are indicated in kilobase pairs. 
analyses of the selected clone showed that free plasmid was no longer detected (Fig. 1B, lane 3). Hybridization patterns also revealed the absence of the 2.9-kbp wild-type fragment, suggesting that recombination had occurred in this region. In addition, the detection of a EcoRV fragment of $10.2 \mathrm{kbp}$ and EcoRVPstI fragments of 6 and $1.9 \mathrm{kbp}$ hybridizing with the probe (Fig. 1C, lanes 1 and 3) confirmed that, in this particular clone, pAA4 had integrated into the spiroplasmal chromosome by a single crossover recombination at $p t s G$, as illustrated in Figure 2. Disruption of $p t s G$ was further documented by polymerase chain reaction (PCR) (data not shown) and Northern blot analy-

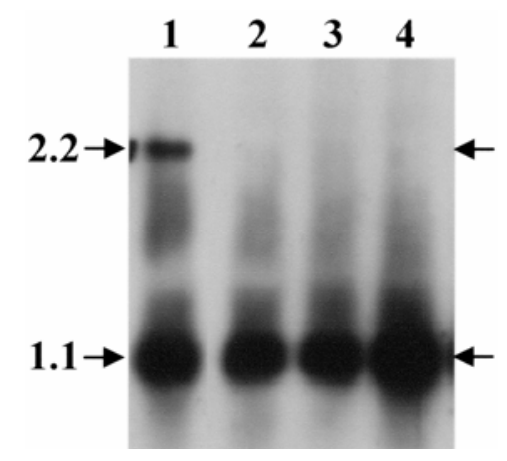

Fig. 3. Northern blot hybridization between total RNAs and probes specific for spiralin and ptsG. Total RNAs extracted from Spiroplasma citri wild-type strain GII-3 grown in HSI medium (Whitcomb 1983) supplemented with glucose (lane 1) and $p t s G$-disrupted mutant GII3-glc1 (lanes 2 to 4) grown in HSI medium supplemented with glucose (lane 2), fructose (lane 3), or trehalose (lane 4). The hybridization was carried out with a mixture of both probes $p t s G$ and spiralin (used as the control).

A
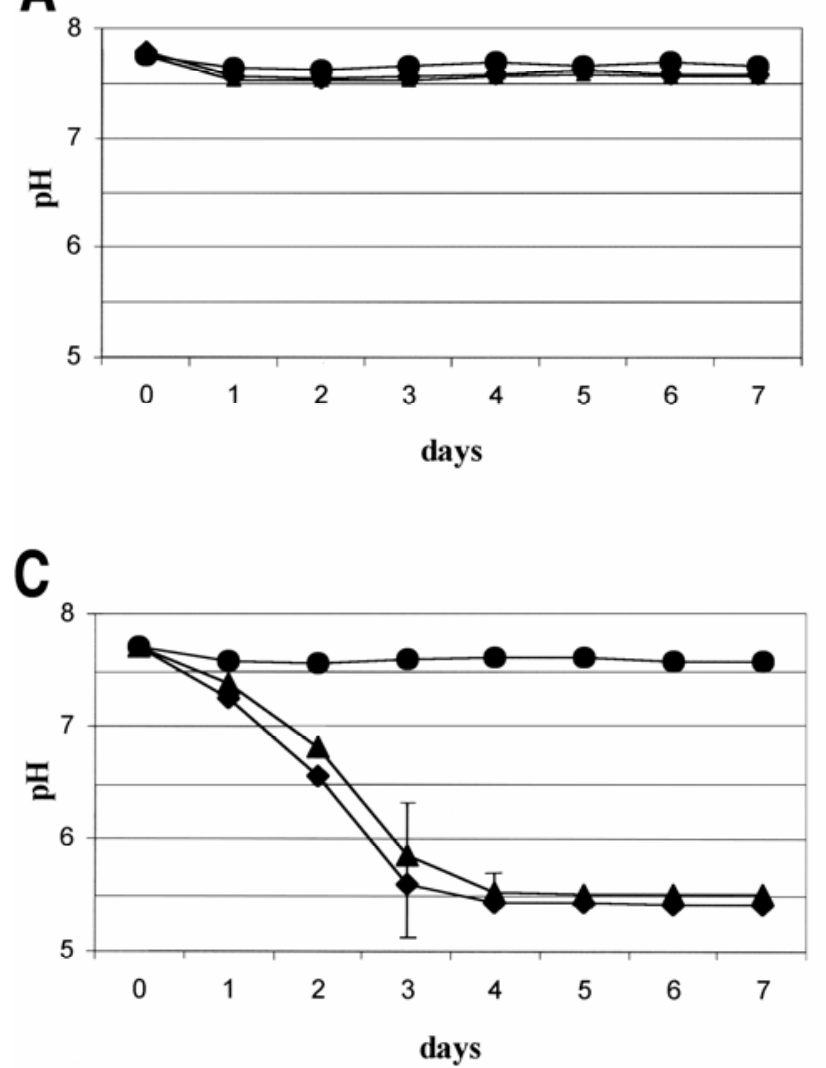

ses (Fig. 3). As shown in the figure, the 2.2-kbp ptsG transcript was not detected in the ptsG-disrupted mutant regardless of the sugar added to the medium and, in particular, in the presence of glucose, which was previously shown to stimulate transcription of the glucose permease gene (André et al. 2003). Before further experiments, the ptsG-disrupted mutant, which we named $S$. citri GII3-glc1, was triply cloned, to avoid the possible occurrence of contaminating, wild-type spiroplasmas.

\section{Sugar catabolism in S. citri GII3-glc1.}

Knowing that carbohydrate fermentation in S. citri essentially results in lactic acid production, sugar metabolism was monitored by measuring the $\mathrm{pH}$ of the culture medium during spiroplasma growth. Three $S$. citri strains were tested: the wild-type strain GII-3, the ptsG-disrupted mutant GII3-glc1, and strain GII3-co, a spiroplasmal transformant in which the disruption plasmid (i.e., the oriC plasmid carrying the $p t s G$ gene fragment) had integrated into the chromosome by recombination at oriC rather than at $p t s G$. For each of the three strains tested, $\mathrm{pH}$ curves were determined in the presence of sorbitol, trehalose, glucose, and fructose (Fig. 4). As expected, all three strains were found to acidify medium supplemented with trehalose or fructose (Fig. 4B and D) but not sorbitol (Fig. 4A). In contrast, while the control strains (GII-3 and GII3-co) metabolized glucose, no $\mathrm{pH}$ decrease was observed in the case of GII3-glc1 (Fig. 4C). These results clearly indicated that $S$. citri GII3-glc1 was unable to import glucose and that this phenotype was due to $p t s G$ gene disruption. In addition, they proved PTS to be the major, if not the only, glucose import system in $S$. citri. Indeed, GII3-glc1 was unable to grow in the presence of glucose as the only carbon source, whereas in the presence of fructose, it grew at the same rate as the wild-type strain GII-3

B
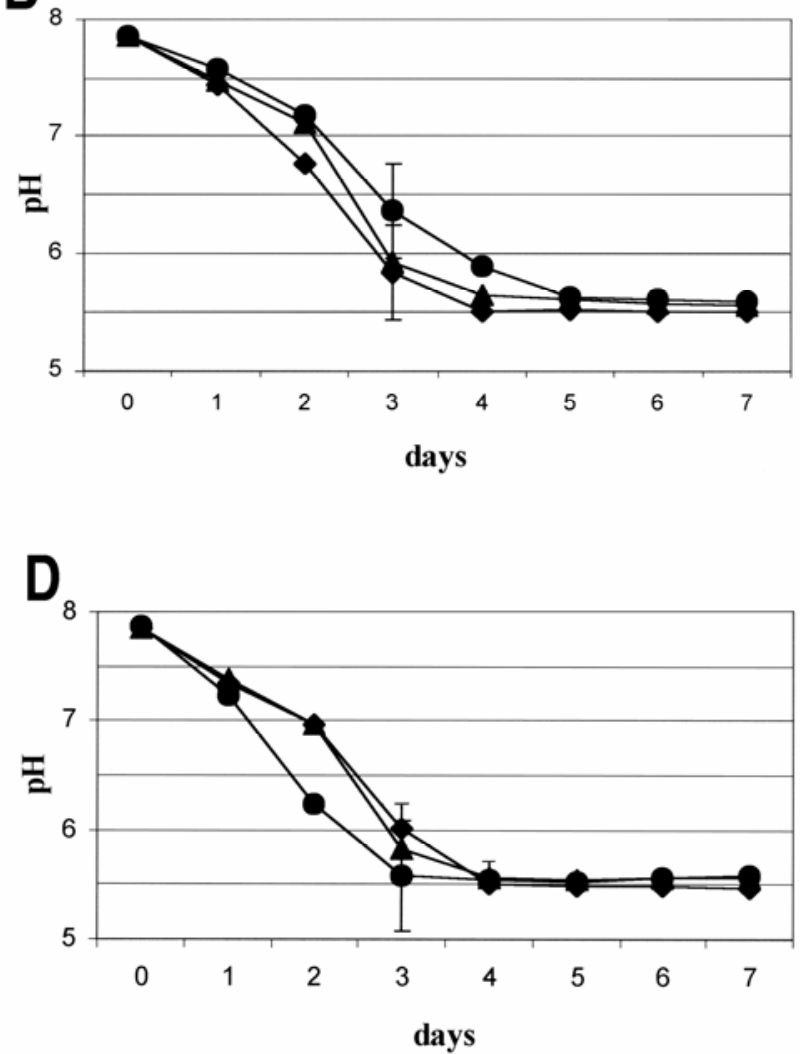

Fig. 4. Carbohydrate utilization by Spiroplasma citri GII-3, GII3-co, and GII3-glc1 as indicated by acidification of HSI medium (Whitcomb 1983) supplemented with A, sorbitol, $\mathbf{B}$, trehalose, $\mathbf{C}$, glucose, and $\mathbf{D}$, fructose. $\bullet=$ S. citri GII-3; $\bullet=$ GII3-glc1; and $\mathbf{\Lambda}=$ GII3-co. 
(Fig. 5). The inability of S. citri GII3-glc1 to use glucose was further confirmed by determining the amount of sugar used by the spiroplasmas. As shown in Table 1, the $S$. citri mutant GII3glc1 and the wild-type strain GII-3 used fructose at approximately the same rate (respectively, 27.5 and $28.2 \mu$ moles in 48 h). However, in contrast to $S$. citri GII-3, S. citri GII3-glc1 used virtually no glucose ( $0.1 \mu$ moles). Interestingly, when both fructose and glucose were present, $S$. citri GII-3 preferentially used fructose, whereas $S$. citri GII3-glc1 used fructose exclusively. The preferential use of fructose over glucose by $S$. citri GII-3 was further confirmed by determining the minimal inhibitory concentrations (MIC) of the toxic, glucose analogue $\alpha$-methylglucopyranose ( $\alpha-\mathrm{MG})$ in the presence of various sugar combinations. The MIC of $\alpha-\mathrm{MG}$ were $5 \%$ in the presence of glucose, $30 \%$ in the presence of fructose, and $30 \%$ in the presence of both glucose and fructose. These results indicated that, in the presence of glucose alone, $\alpha-\mathrm{MG}$ was imported by the spiroplasmas as was the glucose, leading to high toxicity. In contrast, in the presence of both fructose and glucose, $\alpha-\mathrm{MG}$, and hence glucose, were poorly imported as indicated by the low toxicity of $\alpha-\mathrm{MG}$ in this medium. The MIC (30\%) was identical to that determined in the presence of fructose alone.

\section{Pathogenicity of $S$. citri GII3-glc1.}

To determine whether the inability to import glucose had an effect on spiroplasmal pathogenicity, the S. citri mutant GII3glc1 was experimentally transmitted to periwinkle plants through injection to the leafhopper vector Circulifer haematoceps. In these experiments, S. citri GII-3 and GII3-co were used as control strains. Insects were microinjected with spiroplasma cultures and were caged on young periwinkle plants for two weeks. After the transmission period, the infected insects were removed from the plants and were fed on spiroplasma-free SP4 medium through a Parafilm membrane for 24 $\mathrm{h}$, in order to determine the ability of the spiroplasma strains to be transmitted by the insects. The living insects were then captured, and the spiroplasma titers in these insects were determined. The results presented in Table 2 showed that, similarly to the control strains, the $S$. citri mutant GII3-glc1 multiplied

Table 1. Sugar uptake by Spiroplasma citri GII-3 (wild type) and GII3glc1 (pts $G$ mutant) ${ }^{\mathrm{a}}$

\begin{tabular}{lcccc}
\hline S. citri strain & Sugar & HSI + Glc & HSI + Fru & HSI + Glc + Fru \\
\hline GII-3(wild & & & & \\
type) & Glucose & 29.1 & $\ldots$ & 8.4 \\
& Fructose & $\ldots$ & 28.2 & 28.4 \\
GII3-glc1 & & & & \\
(ptsG mutant) & Glucose & 0.1 & $\ldots$ & 0.1 \\
& Fructose & $\ldots$ & 27.5 & 29.3 \\
\hline
\end{tabular}

${ }^{\text {a }}$ The numbers indicate $\mu$ moles of sugar used by $2 \times 10^{9}$ spiroplasma cells in $48 \mathrm{~h}$. to high titer $\left(1.2 \times 10^{6} \mathrm{CFU}\right.$ per insect $)$ in the injected leafhoppers. It was efficiently transmitted to the plants, in which it multiplied and induced severe symptoms as illustrated in Figure 6. Spiroplasmas isolated from these symptomatic plants were shown to display phenotype (unable to use glucose) and genotype (same hybridization patterns) indistinguishable from those of the GII3-glc1 culture injected to the insects, indicating that symptom expression was due to the multiplication of GII3glc1 and not to the presence of contaminants or revertants. The spiroplasma titers of GII3-glc1, both in the insects and in the plants, were not significantly different from those of the control strains. The fact that only nine plants out of 10 were infected by the $S$. citri mutant seems to correlate with the fact that less spiroplasmas were transmitted by the insects through the Parafilm membrane (13.5 CFU per insect for GII3-glc1 versus 23.2 for GII-3, and 21.6 for GII3-co), suggesting that less spiroplasmas might have been introduced into the plants by the insects during the transmission period. This would also explain that, one week after inoculation, the spiroplasma titer of GII3glc 1 in the plants $\left(6.8 \times 10^{4} \mathrm{CFU}\right.$ per $\mathrm{g}$ of midribs) was slightly inferior to those $\left(1.4 \times 10^{5}\right.$ and $1.2 \times 10^{5} \mathrm{CFU}$ per $\left.\mathrm{g}\right)$ of the control strains. As a result, appearance of foliar symptoms in GII3-glc1 infected plants was slightly delayed (5 to 7 days). Consequently, stunting in these plants was less pronounced than in plants infected by the control strains (Fig. 6).

\section{NMR analyses of carbohydrates in plants.}

The effect of $S$. citri infection on carbohydrate accumulation in periwinkle plants was investigated using metabolic profiles

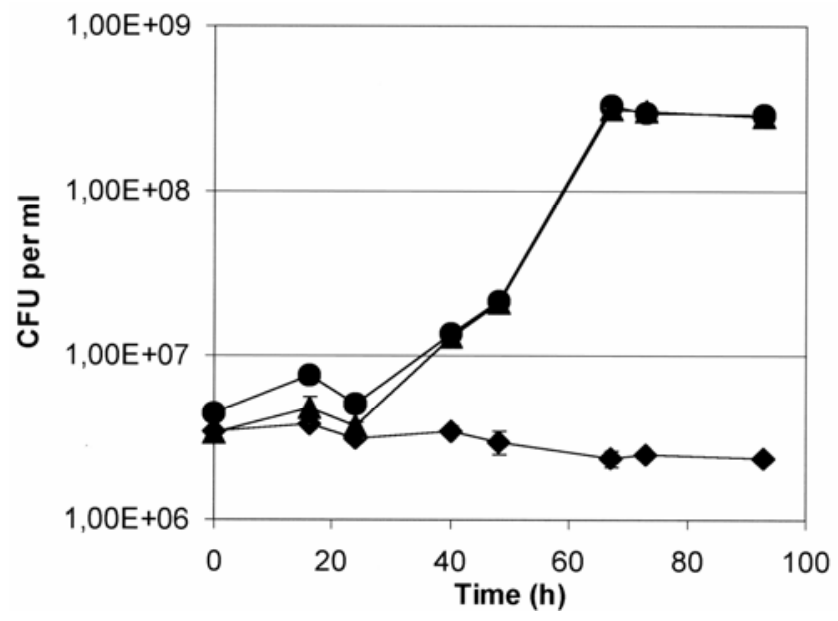

Fig. 5. Growth curves of Spiroplasma citri GII-3 (wild type) and GII3glc1 (ptsG mutant) in HSI medium (Whitcomb 1983) supplemented with glucose or fructose. - S. citri GII-3 in HSI fructose, $\boldsymbol{\nabla}=$ GII3-glc1 in HSI glucose, and $\boldsymbol{\Delta}=$ GII3-glc1 in HSI fructose .

Table 2. Transmission of Spiroplasma citri GII-3 (wild type), GII3-co (control), and GII3-glc1 (ptsG mutant) to periwinkle (Catharanthus roseus) plants through injection to the leafhopper vector (Circulifer haematoceps)

\begin{tabular}{|c|c|c|c|c|c|c|c|}
\hline \multirow[b]{2}{*}{ S. citri strains } & \multirow[b]{2}{*}{ In insects ${ }^{b}$} & \multirow[b]{2}{*}{ Transmission $^{c}$} & \multirow[b]{2}{*}{ Symptomatic plants ${ }^{d}$} & \multicolumn{4}{|c|}{ Weeks posttransmission $^{\mathrm{a}}$} \\
\hline & & & & 1 & 2 & 4 & 6 \\
\hline GII-3 & $1.1 \times 10^{6} \pm 1.8 \times 10^{5}$ & $23.2 \pm 3$ & $5 / 5$ & $1.4 \times 10^{5}$ & $1.5 \times 10^{6}$ & $9.4 \times 10^{6}$ & $1.3 \times 10^{7}$ \\
\hline GII3-co & $1.1 \times 10^{6} \pm 1.7 \times 10^{5}$ & $21.6 \pm 0.9$ & $5 / 5$ & $1.2 \times 10^{5}$ & $2 \times 10^{6}$ & $8.8 \times 10^{6}$ & $9.9 \times 10^{6}$ \\
\hline GII3-glc1 & $1.2 \times 10^{6} \pm 2.1 \times 10^{5}$ & $13.5 \pm 0.5$ & $9 / 10$ & $6.8 \times 10^{4} \mathrm{e}$ & $2.3 \times 10^{6 \mathrm{e}}$ & $9.3 \times 10^{6 \mathrm{e}}$ & $1.2 \times 10^{7 \mathrm{e}}$ \\
\hline
\end{tabular}

a Spiroplasma titers in plants (CFU per gram of midribs).

b Spiroplasma titers in the insects were determined at the end of the transmission period. Each value, indicated as CFU per insect, represents the average of three (GII3-co) or four (GII-3 and GII3-glc1) independent determinations.

c Through parafilm membrane.

${ }^{\mathrm{d}}$ Six weeks posttransmission.

e Average of two determinations. 
through ${ }^{1} \mathrm{H}-\mathrm{NMR}$ analyses. Plants were infected through insect transmission with $S$. citri GII-3, GII3-glc1, and GMT-553, a $S$. citri mutant unable to use fructose that was previously shown to be virtually nonpathogenic (Foissac et al. 1997b; Gaurivaud et al. 2000a). Plants were harvested 5 weeks after infection. Because spiroplasmas are restricted to the phloem sieve tubes, extracts for ${ }^{1} \mathrm{H}-\mathrm{NMR}$ analyses were prepared from both foliar lobes and midribs, which represent a phloem-enriched fraction. Resonances corresponding to various carbohydrates and organic acids were identified and quantified. The results presented in Figures 7 and 8 show that infection by $S$. citri GII-3 (wild type) and GII3-glc1 (ptsG-disrupted mutant), both of which induced severe symptoms, led to the accumulation of glucose in the midribs and foliar lobes and sucrose mainly in the foliar lobes. Sugar concentrations in symptomatic plants were approximately six times higher in the foliar lobes and four times higher in the midribs for glucose and four times higher in the foliar lobes for sucrose. Unexpectedly, fructose was

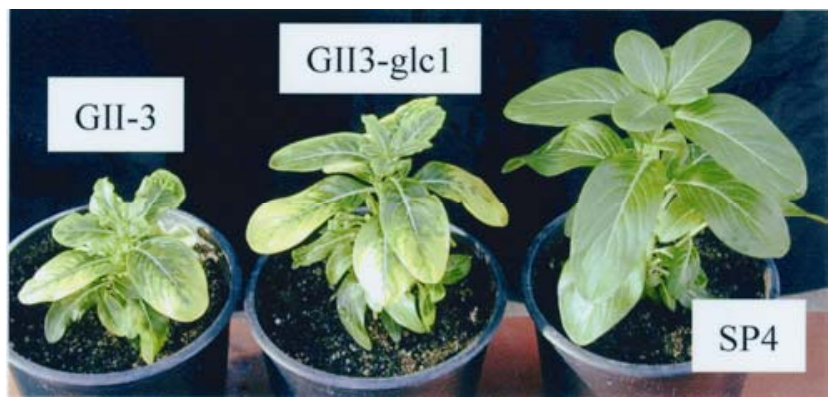

Fig. 6. Symptoms induced in periwinkle plants infected by Spiroplasma citri GII-3 (wild type) and GII3-glc1 (ptsG mutant). Plants were photographed four weeks after the transmission period. SP4 = control plant submitted to insects that were inoculated with spiroplasma-free SP4 medium. found to accumulate in the foliar lobes of GII3-glc1 infected plants but not in plants infected with the wild-type strain GII-3 (Fig. 8). In addition, no fructose accumulation was observed in the midribs of infected plants as compared with those of healthy ones. Galactose (Fig. 7) and raffinose (data not shown) also were found to accumulate (ten- and threefold increases, respectively) both in the foliar lobes and midribs of symptomatic plants, i.e. those infected by $S$. citri GII-3 and GII3-glc1. Concentrations of galactose and raffinose were significantly higher (approximately two times) in GII3-glc1-infected plants than in plants infected by the wild-type strain GII-3. In contrast, the levels of soluble sugars in healthy and in symptomless GMT 553-infected plants were very similar (Figs. 7 and 8). Interestingly enough, no significant accumulation of lactate was detected in the midribs of infected plants, regardless of whether they were infected by $S$. citri GII-3 or GII3-glc1. On the contrary, lactate concentrations were 2.5 times higher in the leaves of healthy and symptomless plants $(5 \mu \mathrm{mol}$ per $\mathrm{g}$ of dry weight) than in the leaves of plants showing severe symptoms $(2 \mu \mathrm{mol}$ per $\mathrm{g}$ of dry weight $)$.

\section{DISCUSSION}

Many phytopathogenic bacteria are exogenous, colonize the apoplast, produce cell wall-degrading enzymes, and possess a type III secretion system to introduce proteins into the host cell as part of pathogenic mechanism (Alfano and Collmer 1996). In contrast, the phloem-restricted bacteria, such as phytoplasmas and spiroplasmas, are endogenous. Through insect transmission, plant pathogenic mollicutes are introduced into and restricted to the phloem sieve tubes, where they have access to nutrients for growth. The disorders they cause originate from the molecular mechanisms by which the bacterial metabolism interferes with the normal plant physiology (Bové et al. 2003; Seemüller et al. 2002). In S. citri, mutants unable to use fructose are virtually

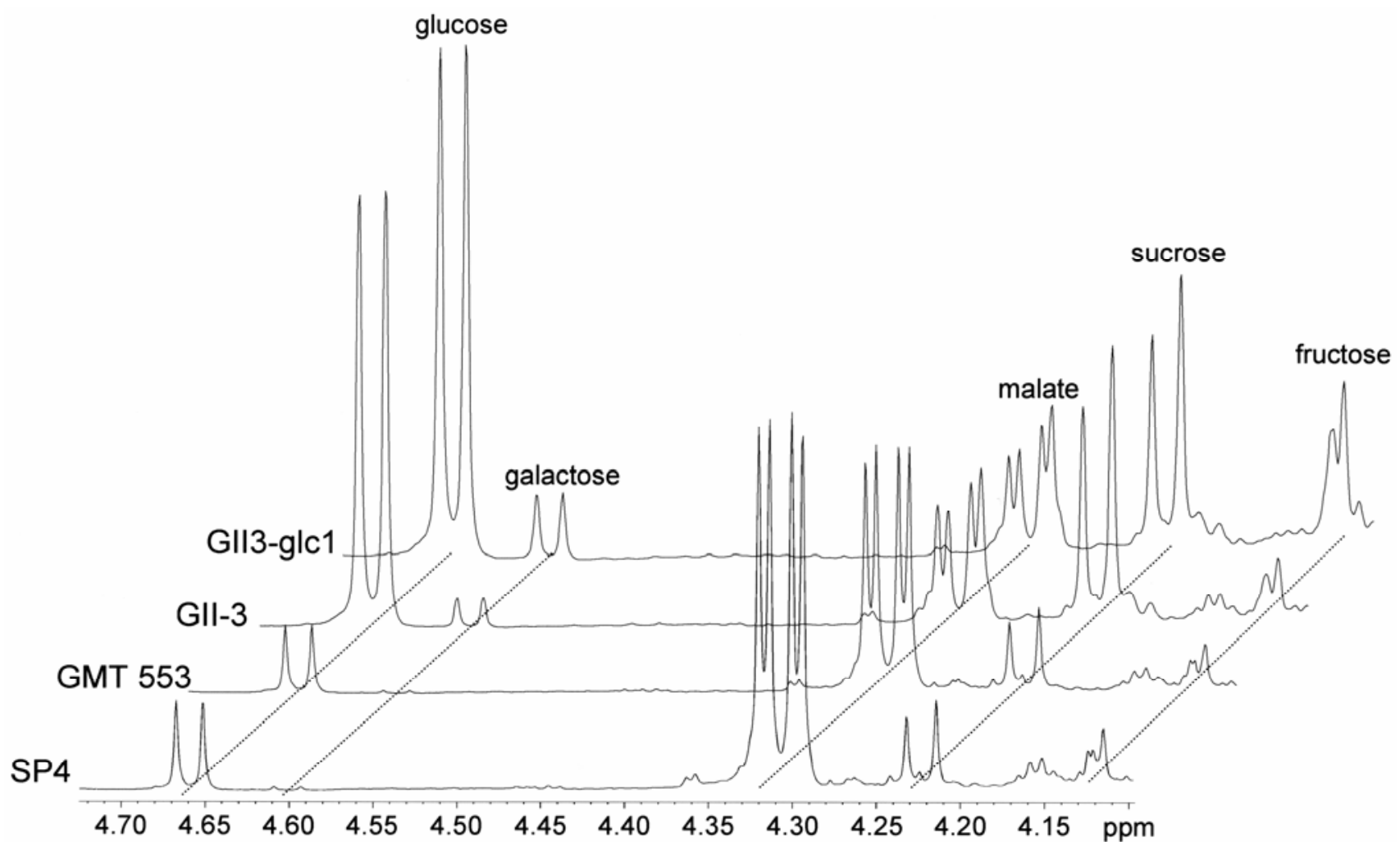

Fig. 7. ${ }^{1} \mathrm{H}$-NMR spectra of glucose, galactose, malate, sucrose, and fructose in foliar lobe extracts from periwinkle plants mock-infected (SP4) or infected by Spiroplasma citri GII-3 (wild type), GII3-glc1 (ptsG mutant), and GMT 553 (fructose operon mutant). 
nonpathogenic, and fructose utilization has been shown to be a key factor of spiroplasmal pathogenicity (Foissac et al. 1997b; Gaurivaud et al. 2000a, b, and c). From these earlier studies, a model mechanism has been proposed in which the spiroplasmas present in the sieve tubes compete with the companion cells for
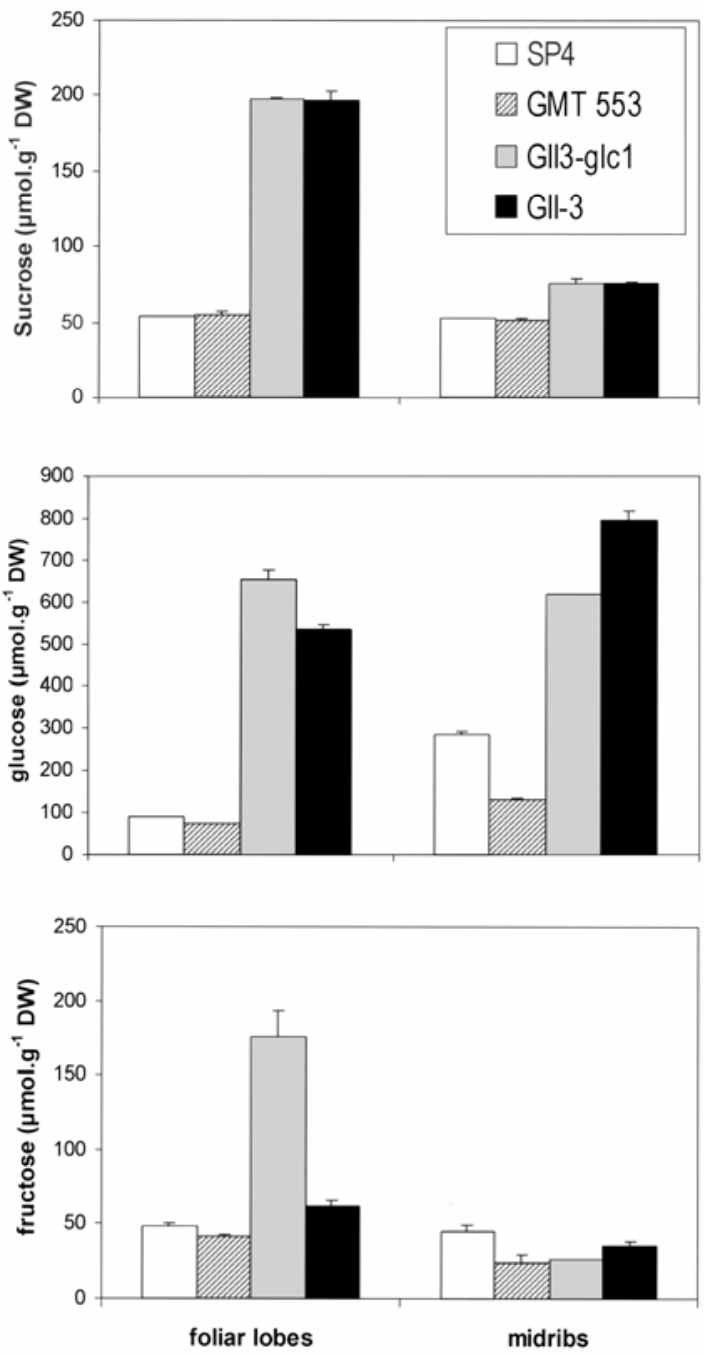

Fig. 8. Quantification of sucrose, glucose, and fructose in foliar lobes and midribs from periwinkle plants mock-infected (SP4) or infected by Spiroplasma citri GII-3 (wild type), GII3-glc1 (ptsG mutant), and GMT 553 (fructose operon mutant), as determined from ${ }^{1} \mathrm{H}-\mathrm{NMR}$ spectra.

A

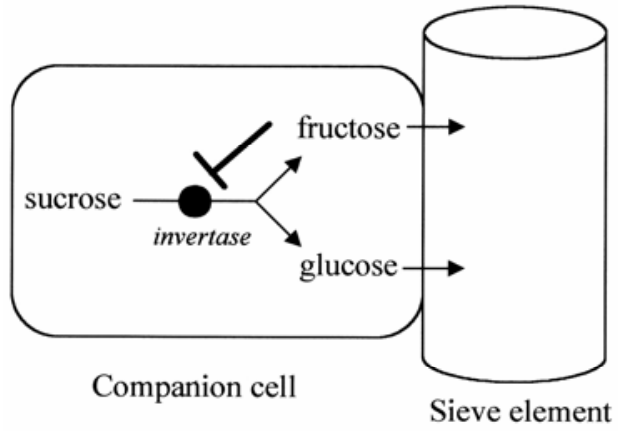

fructose and glucose utilizetion (Bové et al. 2003; Gaurivaud et al. 2000a). In vitro, S. citri uses fructose and glucose equally well (Chang et al. 1994; this study), and it is likely that, in the phloem sap, the two hexoses play the same nutritional role for the spiroplasma growth. Thus, spiroplasma mutants unable to use glucose were expected to display the same phenotype as the fructose mutants. Instead, our present investigations revealed that the $S$. citri mutant GII3-glc1 was highly pathogenic. It multiplied to high titer in the plant and induced symptoms such as leaf yellowing, internode shortening, and stunting, undistinguishable of those induced by the wild-type strain GII-3, except that symptoms appeared with a one-week delay. Such a delay was consistent with the finding that transmission of GII3-glc1 by the leafhopper vector was a little less efficient than that of the wild-type strain GII-3, suggesting that fewer spiroplasmas were introduced into the plants by the insects. Indeed, one week after infection, spiroplasma titer of GII3-glc1 in the plants reached only half that of the control strains. In the insect vector, when $S$. citri moves from the haemolymph to the salivary glands (Fletcher et al. 1998; Kwon et al. 1999), the spiroplasma growth most likely relies on trehalose, the major sugar in the haemolymph, and on glucose in the cells of salivary glands. We have shown previously that the glucose and trehalose PTS permeases share a unique IIA domain, enabling the spiroplasma to adapt quickly from glucose to trehalose and vice versa (André et al. 2003). In the S. citri mutant GII3-glc1, the failure to use glucose might hinder the spiroplasma multiplication in the salivary gland cells, resulting in decreased transmission efficiency.

NMR metabolic profiles of S. citri-infected periwinkles revealed accumulation of soluble sugars and, more particularly, glucose and sucrose in the leaves of symptomatic plants, i. e., those infected by the wild-type strain GII-3 or the $p t s G$-disrupted mutant GII3-glc1 but not in the plants infected by the fructose operon mutant GMT 553. These results are reminiscent of previous studies showing that phytoplasma infections impair translocation of photoassimilates in the phloem (Braun and Sinclair 1978; Catlin et al. 1975), resulting in carbohydrate accumulation in source leaves and depletion in sink organs (Lepka et al. 1999). More recently, similar changes in carbohydrate metabolism have been described in coconut palms infected with the lethal yellowing phytoplasma (Maust et al. 2003). In this case also, phytoplasma multiplication in phloem sieve tubes was shown to impair carbohydrate partitioning, with accumulation of soluble sugars in source leaves. In $S$. citri, lactic acid production by the spiroplasmas in heavily infected plants was thought to contribute to disease symptoms (Daniels 1979), because strong acidification of the phloem sap was shown to affect carbohydrate partitioning (Daniels 1983). In this respect,
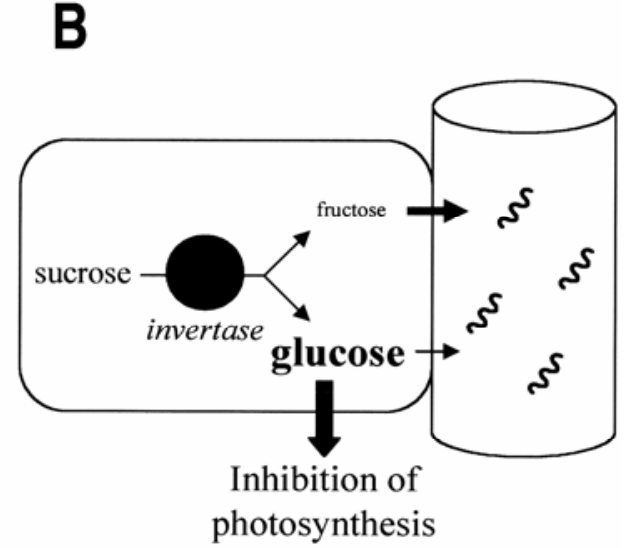

Fig. 9. Hypothetical model showing the putative relationship between fructose utilization by Spiroplasma citri in the phloem sieve tubes and glucose accumulation in mature leaves of infected plants. A, Healthy and B, S. citri infected plant. 
it was hypothesized that the wild-type strain GII-3, which uses both fructose and glucose, might produce more lactic acid and then would be more pathogenic than the fructose mutant GMT 553, which uses only glucose (Gaurivaud et al. 2000a). However, our results indicated that the $S$. citri mutant GII3-glc1, which used only fructose, displayed the same pathogenicity as the wild-type strain GII-3. In addition, proton NMR analyses did not reveal a significant increase of lactate concentration in the midribs of plants infected by GII-3 and GII3-glc1. These data do not sustain the theory that high lactate concentrations produced by $S$. citri actually induce disease symptoms.

Our studies clearly indicate that fructose and glucose utilization do not play similar roles in $S$. citri pathogenicity. The ability to use fructose has been previously correlated with the ability to induce severe symptoms (Gaurivaud et al. 2000a). In contrast, we showed that glucose import by the spiroplasma was not required for multiplication and symptom production in the host plant. We also showed that, when both sugars were present, $S$. citri uses fructose preferentially, suggesting a probable link with the fact that fructose utilization by the spiroplasmas present in the phloem is essential whereas glucose import is not.

In many plants, sucrose represents the major carbohydrate in the phloem sap, and its use relies on cleavage into hexoses by specialized enzymes such as sucrose synthase and invertases. Alkaline invertase functions in the cytosol and acidic invertases in both the vacuole and the cell wall (Dennis and Blakeley 2000). Immunolocalization studies revealed a strong invertase activity around vascular bundles, the vacuolar invertase being more specifically localized around phloem vessels of mature leaves (Kingston-Smith et al. 1999). Invertases are back-regulated by the products of sucrose hydrolysis and, in particular, by fructose (Sampietro 1995; Walker et al. 1997). In the mature leaves, in which fructose may accumulate in the vacuole, inhibition of invertase activity by fructose is thought to efficiently regulate sucrose hydrolysis (Walker et al. 1997). Based on these bibliographic data and on the preferential use of fructose by $S$. citri, we propose a model to further explain the pathogenicity of $S$. citri (Fig. 9). In healthy plants, sucrose is actively imported into the companion cells. In the companion cell vacuole, the acidic invertase hydrolyzes sucrose into glucose and fructose. Due to the feedback inhibition of invertase by fructose, sucrose hydrolysis is limited. Low amounts of glucose and fructose diffuse in the phloem sieve elements, and sucrose is the major transport form of carbohydrates. In S. citri-infected plants, the sieve elements-restricted spiroplasmas use fructose (preferentially to glucose), leading to a reduced fructose concentration in the companion cell and, consequently, to an increase of invertase activity. As a result, more glucose and fructose are produced. Whereas fructose is used by the spiroplasmas as carbon and energy source, glucose is not used and accumulates. In plants, sugars do not only function as metabolic resources and structural constituents of cells. They also act as important regulators of various processes associated with plant growth and development. A wide variety of genes whose products are involved in diverse metabolic pathways and cellular functions are either induced or repressed, depending on the availability of soluble sugars (Koch 1996; Sheen et al. 1999). Here, we can postulate that glucose accumulation favors the repression of enzymes involved in photosynthesis and reserve mobilization. In transgenic plants, overexpression of invertases and hence hexose accumulation is known to reduce the photosynthesis rate (Heineke et al. 1992), leading to plant symptoms such as leaf yellowing and internode shortening (Heineke et al. 1994; Sonnewald et al. 1991; Von Schaewen et al. 1990). Such symptoms are precisely those observed in $S$. citri-infected periwinkle plants, in which glucose accumulation was detected (this study) and chlorophyll content was markedly reduced (Chang 1998). Based on the preferential use of fructose over glucose by the spiroplasmas and the negative regulation of acidic invertase by fructose, the proposed model would explain why the $S$. citri mutant GII3-glc1 is highly pathogenic whereas the fructose mutant GMT 553 is not. Whether or not invertase activity actually increases in $S$. citri-infected plants will be investigated in future work. The fact that a higher fructose concentration was repeatedly detected in the leaves of plants infected by GII3-glc1 as compared with those infected by the wild-type strain GII-3 (Fig. 8), both of which displayed symptoms, is not understood. However it should be noticed that fructose as well as sucrose concentrations in the various tissues were much lower than those of glucose. The increase of sucrose concentration in the mature leaves of symptomatic plants does not cope with an increase of invertase activity in these tissues and seems more likely related to either a deficient sucrose loading, as previously proposed (Bové et al. 2003; Gaurivaud et al. 2000a), a limited sugar transport in the phloem (Maust et al. 2003), or both. Therefore, both model mechanisms, i.e., preferential use of fructose by the spiroplasma leading to increased invertase activity, glucose accumulation, and inhibition of photosynthesis (this study), and reduction of sucrose loading with subsequent impairment of carbohydrate partitioning (Gaurivaud et al. 2000a), might contribute to spiroplasmal pathogenicity.

\section{MATERIALS AND METHODS}

Bacterial strains, transformation, and growth conditions.

Escherichia coli TOP10 ( $\mathrm{F}^{-}$mcrA $\Delta[$ mrr-hsdRMS-mcrBC] Ф80lacZDM15 $\Delta l a c X 74$ deo $\mathrm{R}$ recA1 ara $139 \quad \Delta[$ araleu $] 7697$ gal $\mathrm{U}$ gal $\mathrm{K}$ rps $\mathrm{L}\left[\mathrm{Str}^{\mathrm{r}}\right]$ end $\mathrm{A} 1$ nupG) was used as the host strain for cloning experiments and plasmid propagation. E. coli competent cells (Invitrogen) were transformed by heat shock at $42^{\circ} \mathrm{C}$, and transformants were selected by plating on Luria-Bertani plates containing $50 \mu \mathrm{g}$ of ampicillin per ml. $S$. citri GII-3 wild-type strain was originally isolated from its leafhopper vector Circulifer haematoceps captured in Morocco (Vignault et al. 1980). Spiroplasmas were grown at $32^{\circ} \mathrm{C}$ in SP4 medium from which fresh yeast extract was omitted or in HSI medium (Whitcomb 1983). S. citri GII-3 was transformed by electroporation as previously described (Stamburski et al. 1991), except that transformants were selected in SP4 medium containing $0.5 \%(\mathrm{wt} / \mathrm{vol})$ fructose $\left(\mathrm{SP} 4{ }^{\mathrm{Fru}}\right)$ instead of glucose in the presence of $2 \mu \mathrm{g}$ of tetracycline per $\mathrm{ml}$. The antibiotic concentration was progressively increased from 2 to $15 \mu \mathrm{g} / \mathrm{ml}$ during passaging of the transformants.

\section{Construction of plasmids.}

The $S$. citri oriC plasmids $\mathrm{pC} 1$ and $\mathrm{pC} 2$ have been described previously (Lartigue et al. 2002; Renaudin, 2002). In brief, the shuttle plasmids $\mathrm{pC} 1 / \mathrm{pC} 2$ were obtained by combining the pBS+ vector (Stratagene, La Jolla, Ca, U.S.A.), the tetM gene from $\operatorname{Tn} 916$, and the chromosomal replication origin (oriC) of $S$. citri. In these plasmids, the oriC region has been reduced to a 163-bp fragment corresponding to the minimal sequences required for replication, and transcription of the tet $M$ gene proceeds from the spiralin gene promoter. E. coli transformants were selected in the presence of $50 \mu \mathrm{g}$ of ampicillin per $\mathrm{ml}(E$. coli) or $2 \mu \mathrm{g}$ of tetracycline per $\mathrm{ml}$ (S. citri). The internal ptsG gene fragment was amplified from $S$. citri genomic DNA with primer pair GP6-GP7 and was inserted into the pGEMT-easy vector (Promega, Madison, WI, U.S.A.). Then, the 1.4-kbp fragment carrying the $p t s G$ sequences was rescued from the recombinant plasmid by digestion with $B a m \mathrm{HI}$ plus $B g l \mathrm{II}$ and was inserted into the Bam $\mathrm{HI}$ site of $\mathrm{pC} 1$ to yield the disruption plasmid pAA4. 


\section{DNA and RNA analyses.}

Genomic DNA was extracted from S. citri cells with the Wizard genomic DNA purification kit (Promega). Restricted DNA was fractionated by agarose gel electrophoresis, was blotted on positively charged nylon membranes by the alkali transfer procedure, and was hybridized with appropriate [digoxygenin]dUTP-labeled probes, using standard stringency conditions (Sambrook et al. 1989). Hybridization signals were detected with anti-digoxygenin-alkaline phosphatase-conjugate and HNPP (2-hydroxy-3-naphtoic acid-2'-phenylanilide phosphate) as the substrate, following the supplier's instructions. Fluorescent signals were detected using a Fluor-S Multimager phosphoimager (Bio-Rad, Hercules, CA, U.S.A.). Total RNAs were extracted from spiroplasma cells by using the Tri-reagent (Sigma, St. Louis). The RNA samples were treated with RQ1 RNase-free DNase (Promega), were separated by agarose gel electrophoresis, and were transferred to charged nylon membranes, according to standard procedures (Sambrook et al. 1989). Hybridization with the appropriate probes was performed as described above for Southern blots, except that washing was carried out at $50^{\circ} \mathrm{C}$. The $p t s G$ probe was generated by PCR amplification of $S$. citri genomic DNA with primers GP6 and GP7 in the presence of [digoxygenin]dUTP. Primers GP6 (5'GACCACGGATCCGCATTCCGGTGCTGC-3') and GP7 (5'TTATAAAGATCTAGTTAAAGGGAATGTTACTG-3') correspond, respectively, to nucleotides 2,421 to 2,447 and 994 to 1,025 of the region surrounding the $p t s G$ gene (GenBank accession number AY230007) (André et al. 2003).

\section{Carbohydrate fermentation.}

Catabolism of carbohydrates in S. citri results in production of lactic and acetic acids that are released in the medium ensuing acidification (Miles 1992). S. citri growth requires complex media supplemented with calf serum bringing carbohydrates and enzymes such as invertases, which may interfere with fermentation of sugars added to the medium. For these reasons, we used HSI medium in which the horse serum was replaced by $1 \%$ PPLO serum fraction (Whitcomb 1983). This sugar-free medium was used for monitoring carbohydrate fermentation, essentially as described previously (Gaurivaud et al. 2000a). S. citri cells grown to the mid-log phase in $10 \mathrm{ml}$ of SP4 medium were harvested by centrifugation $(12,000 \times g, 15$ min), were washed twice, and were resuspended in $1 \mathrm{ml}$ of HEPES-sorbitol buffer (HEPES, $8 \mathrm{mM}$, pH 7.4, sorbitol $10 \%$ [wt/vol]). Two milliliters of HSI medium supplemented with $0.5 \%$ glucose, fructose, trehalose, or sorbitol were inoculated with $5 \times 10^{8}$ washed cells. Sugar fermentation was followed by $\mathrm{pH}$ measurements every $24 \mathrm{~h}$ during 7 days.

\section{Determination of the $\alpha$-methylglucopyranose MIC.}

The MIC of $\alpha$-methylglucopyranose $(\alpha-M G)$ was determined in HSI medium containing glucose, fructose, trehalose, or fructose plus glucose as carbon sources. $S$. citri cells grown in SP4 medium were washed twice and were resuspended in 8 $\mathrm{mM}$ HEPES, $\mathrm{pH} 7.4,10 \%$ sorbitol. HSI medium supplemented with $0.5 \%$ sugar and containing $\alpha-\mathrm{MG}$ at concentrations ranging from 0 to $50 \%$ (wt/vol) was inoculated with $5 \times$ $10^{8}$ washed cells, and the cultures were incubated at $32^{\circ} \mathrm{C}$ for one week. The MIC of $\alpha-M G$ was determined as the lowest concentration preventing acidification of the medium.

\section{Biochemical dosages in culture medium.}

Fructose, glucose, and lactic acid concentrations in the culture medium were determined with the TC glucose/fructose/sucrose and TC lactic acid kits from Roche Diagnostics (Meylan, France), following the supplier's recommendations. For determinations, spiroplasmas $\left(2 \times 10^{9} \mathrm{CFU}\right)$ were grown in $2 \mathrm{ml}$ of
HSI medium supplemented with $0.5 \%$ (wt/vol) of the appropriate sugar.

\section{Experimental transmission assay.}

Microinjection of S. citri into Circulifer haematoceps leafhoppers and transmission to the periwinkle host plant (Catharanthus roseus) were described elsewhere (Foissac et al. 1996, 1997b). Briefly, the insects were microinjected with $10^{5}$ to $10^{6}$ spiroplasma cells, and the injected insects were caged on 6week-old periwinkle plants (12 insects per plant, 5 to 10 plants per spiroplasma strain) for a 2 -week transmission period. After transmission, the insects were removed, and the plants were kept in the greenhouse at $30^{\circ} \mathrm{C}$ for symptom development. Culture of $S$. citri from plants and insects as well as transmission through Parafilm membranes have been described previously (Foissac et al. 1996, 1997b). Titers of $S$. citri in the insects were determined at the end of the transmission period. In the plants, titers were determined every two weeks for the six weeks following the transmission period. For transmission through Parafilm membrane, groups of five living insects were removed from the plants at the end of the transmission period and were fed through the membrane on sterile SP4 medium supplemented with $5 \%$ sucrose. After a $24-\mathrm{h}$ feeding period, the number of spiroplasmas inoculated in the medium by the insects was determined by plating onto SP4 ${ }^{\mathrm{Fru}}$ plates.

\section{Extraction of metabolites from plants.}

The midribs and foliar lobes of leaves from periwinkle plants were reduced to powder in liquid nitrogen and were lyophilized. For each tissue, three subsamples, each of $50 \mathrm{mg}$ of dried powder, were extracted successively with $2 \mathrm{ml}$ of $80 \%$ ethanol, $50 \%$ ethanol, and pure water at $80^{\circ} \mathrm{C}$ for $15 \mathrm{~min}$. The three supernatants were combined and centrifuged for $10 \mathrm{~min}$ at $30,000 \times$ $g$. The resulting supernatant was frozen and dried under vacuum for one night and then were lyophilized for $24 \mathrm{~h}$. To improve spectrum resolution, paramagnetic cations, e.g., $\mathrm{Mn}^{++}$, were eliminated, using Chelex 100 resin (Bio-Rad). For this purpose, the dried extracts were solubilized with $5 \mathrm{ml}$ of pure water added with $500 \mathrm{mg}$ Chelex 100 and titrated to $\mathrm{pH} 5.5 \pm 0.3$ with $\mathrm{HCl}$. After $1 \mathrm{~h}$ of mixing at $4^{\circ} \mathrm{C}$, the supernatant was collected and the resin was rinsed three times with $1 \mathrm{ml}$ of pure water. The three supernatants were combined, frozen in liquid nitrogen, and lyophilized for $24 \mathrm{~h}$. The dried purified extracts were solubilized in $400 \mathrm{mM}$ phosphate buffer in $\mathrm{D}_{2} \mathrm{O}$ and were titrated to $\mathrm{pH} 6.0$ \pm 0.05 with $1 \mathrm{M} \mathrm{KOH}$ in $\mathrm{D}_{2} \mathrm{O}$. After $2 \mathrm{~h}$ of equilibration at $4^{\circ} \mathrm{C}$, the titrated extracts were frozen in liquid nitrogen and lyophilized for $24 \mathrm{~h}$. The dried purified titrated extracts were stored under dry atmosphere before ${ }^{1} \mathrm{H}-\mathrm{NMR}$ analysis.

\section{${ }^{1}$ H-NMR spectroscopy of plant extracts.}

The dried purified titrated extracts were dissolved in $0.5 \mathrm{ml}$ of $\mathrm{D}_{2} \mathrm{O}$. Sodium salt of (trimethyl) propionic-2,2,3,3-d4 acid (TSP) in $\mathrm{D}_{2} \mathrm{O}$ was added in all samples at a final concentration of $0.01 \%$, for chemical shift calibration. One-dimensional ${ }^{1} \mathrm{H}-$ NMR spectra were recorded at $500.162 \mathrm{MHz}$ at $300 \mathrm{~K}$ on a Bruker Avance spectrometer, using a $5 \mathrm{~mm}$ inverse probe. Sixty-four scans of 64,000 data points were acquired with a spectral width of $6,000 \mathrm{~Hz}$, acquisition time of $2.73 \mathrm{~s}$, and recycle delays of $20 \mathrm{~s}$. The ERETIC method (electronic reference to access in vivo concentrations) was used for quantification of absolute concentrations of metabolites (Akoka et al. 1999) with calibration curves of $\mathrm{C} 1 \mathrm{H}-(\alpha+\beta)$ glucose. Preliminary data processing was carried out with XWINNMR software (Bruker Biospin, Karlsruhe, Germany). FIDs were Fouriertransformed $(0.5 \mathrm{~Hz}$ line broadening), phased, and baselinecorrected. The resulting spectra were aligned by shifting TSP signal to zero. Each major metabolite of the extracts was iden- 
tified after peak assignment using ${ }^{1} \mathrm{H}-\mathrm{NMR}$ spectra from pure compounds associated with comparison of published data (Fan 1996; Le Gall et al. 2003). When further confirmation of the assignment was required, the plant extracts were spiked with appropriate standards to confirm that the chemical shifts were identical. Concentrations of soluble sugars (sucrose, fructose, glucose, galactose, and raffinose) and organic acids (lactate and malate) were calculated using metabolite mode of AMIX software (Bruker) for calculation of resonance areas, followed by data export to Excel software and quantification using the glucose calibration curve and the proton amount corresponding to each resonance.

\section{ACKNOWLEDGMENTS}

This work was funded by INRA, University Victor Segalen Bordeaux2 and Région Aquitaine. We thank our colleagues J. L. Danet for injecting spiroplasma cultures into the insects, S. Duret-Nurbel for technical expertise, and X. Foissac for sharing DNA sequence information. Support for A. André was provided by the Ministère de l'Enseignement Supérieur et de la Recherche.

\section{LITERATURE CITED}

Akoka, S., Barantin, L., and Trierweiler, M. 1999. Concentration measurement by proton NMR using the ERETIC method. Anal. Chem. 71:2554-2557.

Alfano, J. R., and Collmer, A. 1996. Bacterial pathogens in plants: Life up against the wall. Plant Cell 8:1683-1698.

André, A., Maccheroni, W., Doignon, F., Garnier, M., and Renaudin, J. 2003. Glucose and trehalose PTS permeases of Spiroplasma citri probably share a single IIA domain, enabling the spiroplasma to adapt quickly to carbohydrate changes in its environment. Microbiology 149:2687-2696.

Boutareaud, A., Danet, J. L., Garnier, M., and Saillard, C. Disruption of a gene predicted to encode a soluble binding protein of an ABC transporter reduces transmission of Spiroplasma citri by the leafhopper Circulifer haematoceps. Appl. Environ. Microbiol. 70:3960-3967.

Bové, J. M. 1997. Spiroplasmas: Infectious agents of plants, arthropods, and vertebrates. Wien. Klin. Wochenschr. 109:604-612.

Bové, J. M., Carle, P., Garnier, M., Laigret, F., Renaudin, J. and Saillard, C. 1989. Molecular and cellular biology of spiroplasmas. Pages 243364 in: The Mycoplasmas, Vol. V. R. F. Whitcomb and J. G. Tully, eds. Academic Press. New York.

Bové, J. M., Renaudin, J., Saillard, C., Foissac, X., and Garnier, M. 2003. Spiroplasma citri, a plant pathogenic mollicute: Relationships with its two hosts, the plant and the leafhopper vector. Annu. Rev. Phytopathol. 41:483-500.

Braun, E. J., and Sinclair, W. A. 1978. Translocation in phloem necrosisdiseased American elm seedlings. Phytopathology 68:1733-1737.

Catlin, P. B., Olsson, E. A., and Beutel, J. A. 1975. Reduced translocation of carbon and nitrogen from leaves with symptoms of pear curl. J. Am. Soc. Hortic. Sci. 100:184-187.

Chang, C. J. 1998. Pathogenicity of aster yellows phytoplasma and S. citri on periwinkle. Phytopathology 88:1347-1350.

Chang, C. J., Renaudin, J., and Bové, J. M. 1994. Nutritional requirements of Spiroplasma citri. Int. Organ. Mycoplasmol. Lett. 3:518.

Chino, M., Hayashi, H., Nakumura, S., Oshima, T., Turner, H., Sabnis, D., Borkovec, V., Baker, D., Girousse, G., Bonnemain, J. L., and Delrot, S. 1991. Phloem sap composition. Pages 64-73 in: Recent Advances in Phloem Transport and Assimilate Compartmentation. J. L. Bonnemain, S. Delrot S, W. J. Lucas, J. Dainty, eds. Ouest Editions, Presses Académiques. Paris.

Daniels, M. J. 1979. A simple method for assaying certain microbioal phytotoxins and its application to the study of toxins by Spiroplasma citri. J. Gen. Microbiol. 114:323-328.

Daniels, M. J. 1983. Mechanisms of spiroplasma pathogenicity. Annu. Rev. Phytopathol. 21:29-43.

Dennis, D. T., and Blakeley, S. D. 2000. Carbohydrate metabolism. Pages 630-676 in: Biochemistry and Molecular Biology of Plants. B. Buchanan, W. Gruissem, and R. Jones, eds. American Society of Plant Physiologists, Rockville, MD, U.S.A

Duret, S., Berho, N., Danet, J. L., Garnier, M., and Renaudin, J. 2003. Spiralin is not essential for helicity, motility, or pathogenicity but is required for efficient transmission of Spiroplasma citri by its leafhopper vector Circulifer haematoceps. Appl. Environ. Microbiol. 69:6225-6234.
Duret, S., Danet, J. L., Garnier, M., and Renaudin, J. 1999. Gene disruption through homologous recombination in Spiroplasma citri: An scm 1disrupted motility mutant is pathogenic. J. Bacteriol. 181:7449-7456.

Fan, T. W. M. 1996. Metabolite profiling by one- and two-dimensional NMR analysis of complex mixtures. Prog. Nucl. Mag. Res. Sp. 28:161219.

Fletcher, J. 1983. Brittle root of horseradish in Ilinois and the distribution of Spiroplasma citri in the United States. Phytopathology 73:354-357.

Fletcher, J., Wayadande, A., Melcher, U., and Ye, F. 1998. The phytopathogenic mollicute-insect vector interface: A closer look. Phytopathology 88:1351-1358

Foissac, X., Danet, J. L., Saillard, C., Whitcomb, R. F., and Bové, J. M. 1996. Experimental infection of plants by spiroplasmas. Pages 385-389 in: Molecular and Diagnostic Procedures in Mycoplasmology, Vol. 2. S. Razin and J. G. Tully, eds. Academic Press. New York.

Foissac, X., Saillard, C., and Bové, J. M. 1997a. Random insertion of Tn4001 in the genome of Spiroplasma citri strain GII-3. Plasmid 37:8086.

Foissac, X., Saillard, C., Danet, J. L., Gaurivaud, P., Paré, C., Laigret, F., and Bové, J. M. 1997b. Mutagenesis by insertion of transposon Tn4001 into the genome of Spiroplasma citri: Characterization of mutants affected in plant pathogenicity and transmission to the plant by the leafhopper vector Circulifer haematoceps. Mol. Plant-Microbe Interact. 10:454-461.

Gaurivaud, P., Danet, J. L., Laigret, F., Garnier, M., and Bové, J. M. 2000a. Fructose utilization and pathogenicity of Spiroplasma citri. Mol. Plant-Microbe Interact. 13:1145-1155.

Gaurivaud, P., Laigret, F., Garnier, M., and Bové, J. M. 2000b. Fructose utilization and pathogenicity of Spiroplasma citri: Characterization of the fructose operon. Gene 252:61-69.

Gaurivaud, P., Laigret, F., Verdin, E., Garnier, M., and Bové, J. M. 2000c. Fructose operon mutants of Spiroplasma citri. Microbiology 146, 2229 2236.

Heineke, D., Sonnewald, U., Büssis, D., Günter, G., Leidreiter, K., Wilke, I., Raschke, K., Willmitzer, L., and Heldt, H. W. 1992. Apoplastic expression of yeast-derived invertase in potato: Effects on photosynthesis, leaf solute composition, water relation, and tuber composition. Plant Physiol. 100:301-308.

Heineke, D., Wildenberg, K., Sonnewald, U., Willmitzer, L., and Heldt, H. W. 1994. Accumulation of hexoses in leaf vacuoles: Studies with transgenic tobacco plants expressing yeast-derived invertase in the cytosol, vacuole or apoplasm. Planta 194:29-33.

Jacob, C., Nouzières, F., Duret, S., Bové, J. M., and Renaudin, J. 1997. Isolation, characterization, and complementation of a motility mutant of Spiroplasma citri. J. Bacteriol. 179:4802-4810.

Kingston-Smith, A. H., Walker, R. P., and Pollock, C. J. 1999. Invertases in leaves: Conundrum or control point? J. Exp. Bot. 50:735-743.

Koch, K. E. 1996. Carbohydrate-modulated gene expression in plants. Annu. Rev. Plant Physiol. Plant Mol. Biol. 47:477-508.

Kwon, M., Wayadande, A. C., and Fletcher, J. 1999. Spiroplasma citri movement into the intestines and salivary glands of its leafhopper vector, Circulifer tenellus. Phytopathology 89:1144-1151.

Lartigue, C., Duret, S., Garnier, M., and Renaudin, J. 2002. New plasmid vectors for specific gene targeting in Spiroplasma citri. Plasmid 48:149. 159.

Lee, I.-M., Davis, R. E., and Gundersen-Rindal, D. E. 2000. Phytoplasma: Phytopathogenic mollicutes. Annu. Rev. Microbiol. 54:221-255.

Le Gall, G., Puaud, M., and Colquhoun, I. J. 2001. Discrimination between orange juice and pulp wash by ${ }^{1} \mathrm{H}$-nuclear magnetic resonance spectroscopy: Identification of marker compounds. J. Agr. Food Chem. 49:580588.

Lepka, P., Stitt, M., Moll, E., and Seemüller, E. 1999. Effect of phytoplasmal infection on concentration and translocation of carbohydrates and amino acids in periwinkle and tobacco. Physiol. Mol. Plant Pathol. 55:59-68

Maust, B. E., Espedas, F., Talavera, C., Aguilar, M., Santamaria, J. M., and Orpeza, C. 2003. Changes in carbohydrate metabolism in coconut palms infected with the lethal yellowing phytoplasma. Phytopathology 93:976-981.

McCoy, R. E., Caudwell, A., Chang, C. J. Chen, T. A., Chiykowski, L. N., Cousin, M. T., Dale, J. L., DeLeeuw, G. T., Golino, D. A., Hackett, K. J., Kirkpatrick, B. C., Marwitz, R., Petzold, H., Sinha, R. C,. Sugiura, M., Whitcomb, R. F., Yang, I. L., Zhu, B. M., and Seemüller, E. 1989. Plant diseases associated with mycoplasma-like organisms. Pages 545640 in: The Mycoplasmas, Vol. V. R. F. Whitcomb and J. G. Tully, eds. Academic Press. New York.

Miles, R. J. 1992. Catabolism in mollicutes. J. Gen. Microbiol. 138:17731783.

Renaudin, J. 2002. Extrachromosomal elements and gene transfer. Pages 347-370 in: Molecular Biology and Pathogenicity of Mycoplasmas. S. 
Razin and R. Herrmann, eds. Kluwer Academic/Plenum Publishers, New York.

Renaudin, J., Marais, A., Verdin, E., Duret, S., Foissac, X., Laigret, F., and Bové, J. M. 1995. Integrative and free Spiroplasma citri oriC plasmids: Expression of the Spiroplasma phoeniceum spiralin in Spiroplasma citri. J. Bacteriol. 177:2800-2877.

Saglio, P., Laflèche, D., Bonissol, C., and Bové, J. M. 1971. Culture in vitro des mycoplasmes associés au stubborn des agrumes et leur observation au microscope électronique. CR Acad. Sci. Paris 272:13871390.

Saglio, P., Lhospital, M., Laflèche, D., Dupont, G., Bové, J. M., Tully, J. G., and Freundt, E. A. 1973. Spiroplasma citri gen. and sp. n.: A mycoplasma-like organism associated with "stubborn" disease of citrus. Int. J. Syst. Bacteriol. 23:191-204.

Sambrook, J., Fritsch, E. F., and Maniatis, T. 1989. Molecular Cloning: A Laboratory Manual, 2nd ed. Cold Spring Harbor Laboratory Press. Cold Spring Harbor, NY, U.S.A.

Sampietro, A. R. 1995. The plant invertases. Pages 65-71 in: Sucrose Metabolism, Biochemistry, Physiology, and Molecular Biology. G. L. Salerno and E. J. Echeverria, eds. American Society of Plant Physiologists, Rockville, MD, U.S.A.

Seemüller, E., Marcone, C., Lauer, U., Ragozzino, A., and Göschl, M. 1998. Current status of molecular classification of the phytoplasmas. J. Plant Pathol. 80:3-26.

Seemüller, E., Garnier, M., and Schneider, B. 2002. Mycoplasmas of plants and insects. Pages 91-115 in: Molecular Biology and Pathogenicity of Mycoplasmas. S. Razin and R. Herrmann, eds. Kluwer Academic/Plenum Publishers, New York.

Sheen, J., Zhou, L., and Jang, J. C. 1999. Sugars as signaling molecules. Curr. Opin. Plant Biol. 2:410-418.

Sonnewald, U., Brauer, M., von Schaeven, A., Stitt, M., and Willmitzer, L. 1991. Transgenic tobacco plants expressing yeast-derived invertase in either the cytosol, vacuole or apoplast: A powerful tool for studying sucrose metabolism and sink-source interactions. Plant J. 1:95-106.
Stamburski, C., J. Renaudin, and J. M. Bové. 1991. First step toward a virusderived vector for gene cloning and expression in spiroplasmas, organisms which read UGA as a tryptophan codon: Synthesis of chloramphenicol acetyltransferase in Spiroplasma citri. J. Bacteriol. 173:2225-2230.

Vignault, J. C., Bové, J. M., Saillard, C., Vogel, R., Faro, A., Venegas, L., Stemmer, W., Aoki, S., McCoy, R. E., Al-beldawi, A. S., Larue, M., Tuzcu, O., Ozsan, M., Nhami, A., Abassi, M., Bonfils, J., Moutous, G., Fos, A., Poutiers, F., and Viennot-Bourgin, G. 1980. Mise en culture de spiroplasmes à partir de matériel végétal et d'insectes provenant de pays circum méditerranéens et du Proche Orient. CR Acad. Sci. Ser. III Sci. Vie 290:775-780.

Von Schaeven, A., Stitt, M., Schmidt, R., Sonnewald, U., Willmitzer, L. 1990. Expression of a yeast-derived invertase in the cell wall of tobacco and Arabidopsis plants leads to accumulation of carbohydrate and inhibition of photosynthesis and strongly influences growth and phenotype of transgenic tobacco plants. EMBO (Eur. Mol. Biol. Organ.) J. 9:30333044.

Walker, R. P., Winters, A. L., and Pollock, C. J. 1997. Purification and characterization of invertases from leaves of Lolium temulentum L. New Phytol. 135:259-266.

Weisburg, W. G., Tully, J. G., Rose, D. L., Petzel, J. P., Oyaizu, H., Yang, D., Mandelco, L., Sechrest, J., Lawrence, T. G., Van Etten, J., Maniloff, J., and Woese, C. R. 1989. A phylogenetic analysis of the mycoplasmas: Basis for their classification. J. Bacteriol. 171:6455-6467.

Whitcomb, R. F. 1983. Culture media for spiroplasmas. Pages 147-159 in Methods Mycoplasmol, Vol. I. S. Razin and J. G. Tully, eds. Academic Press. New York.

Ye, F., Renaudin, J., Bové, J. M., and Laigret, F. 1994. Cloning and sequencing of the replication origin (oriC) of the Spiroplasma citri chromosome and construction of autonomously replicating artificial plasmids. Curr. Microbiol. 29:23-29.

Ziegler, H. 1975. Nature of transported substances. Pages 59-100 in: Transport in Plants I. Phloem Transport. Encyclopedia of Plant Physiology, Vol. 1. M. H. Zimmerman and J. A. Milburn, eds. Springer-Verlag. Berlin. 